International Journal of Agriculture, Environment and Bioresearch

Vol. 4, No. 04; 2019

ISSN: $2456-8643$

\title{
GROWTH RESPONSE OF Adansonia digitata(Linn) SEEDS AND SEEDLINGS TO DIFFERENT LEVELS OF SPENT LUBRICATING OIL (SLO) CONTAMINTED SOILS
}

\author{
Ojo M.O \\ Forestry Research Institute of Nigeria, Ibadan, Oyo State, Nigeria \\ http://doi.org/10.35410/IJAEB.2019.4422
}

\begin{abstract}
The performance of Adansonia digitata (Linn) seeds and seedlings in spent lubricating oil contaminated soil was evaluated at Federal College of Forestry, Ibadan Oyo State, Nigeria with a view to determine the level of spent lubricating oil that the plant can tolerate. The experimental design used was Completely Randomized Design (CRD) with four replications. The spent lubricating oil levels were $0 \mathrm{ml}, 20 \mathrm{ml}, 40 \mathrm{ml}, 60 \mathrm{ml}, 80 \mathrm{ml}, 100 \mathrm{ml} 120 \mathrm{ml}, 140 \mathrm{ml}$ with $3 \mathrm{~kg}$ of top soil. The parameters assessed were germination percentage $(\%)$, plant height $(\mathrm{cm})$ stem diameter $(\mathrm{mm})$ and leaf production and leaf area $(\mathrm{cm} 2)$. Seedlings were watered once in a day. After fifteen weeks of observation and data collection, it was observed that the seedlings in oil contaminated soil gave different responses to the level of spent lubricating oil concentrations, However, T2 $(20 \mathrm{ml}$ of SLO $+3 \mathrm{~kg}$ of top soil) gave the best performance in seedling height $(9.63 \mathrm{~cm})$, leaf production $(5.15)$, while $\mathrm{T} 5(80 \mathrm{ml}$ of $+3 \mathrm{~kg}$ of top soil) gave the best performance in leaf area $(26.78 \mathrm{~cm} 2)$. Furthermore, there was no significant difference among treatments in seedling height $(\mathrm{cm} \neg)$, leaf area $(\mathrm{cm} 2)$ and leaf production at $5 \%$ level of probability but there was significant difference among treatments in stem diameter $(\mathrm{cm} 2)$ at $5 \%$ level of probability. It was therefore recommended that Adansonia digitata should be adopted for reclamation of land where the use of Spent Lubricating Oil is prominent to an extent.
\end{abstract}

Keywords: Adansonia digitata, Spent Lubricating Oil, Germination, Growth.

\section{INTRODUCTION}

Adansonia digitata (Linn) is most wide spread of the specie on the African continent found in hot dry savannah to sub Saharan Africa; the common name is African baobab tree. The trees usually grows as solitary individuals and are large distinctive. Each leaf comprises of five leaflets. The African baobab fruit can grow up to $25 \mathrm{~cm}$ long and it can contain $50 \%$ more calcium than spinach. (Claire. 2008) .Adansonia digitata is a fast growing plant. It takes the seed seven to twelve days to germinate and start growing if the soil is been prepared very well. It can thrive in difficult terrain, .harsh weather, stony area, depleted area of nutrient e.t.c., because it contains hard-fibre (FAO, 1988). Due to its ability to thrive in these conditions, Adansonia digitata will be adopted in this study to determine its growth response to different levels of spent lubricating oil contaminated soils, which can serve in reclaiming oil-contaminated area, eradicating encroachment and controlling environmental pollution. Further more the spent lubricating oil (waste engine oil) is usually obtained after servicing and subsequently draining 
used oil from automobiles and generator engines. The disposal of spent lubricating oil into drainage systems. open vacant plots and farmlands in Nigeria is a common occurrence and is mostly done by auto mechanics and allied artisans with workshop on the road side and open places (Agbogidi. 2010). According to Wang et al., (2010), some of the spent lubricating oil may have foreign substances including synthetic polychlorinated biphenyls and higher concentrations of poly aromatic hydrocarbon (PAHS). and heavy metal which constitutes environmental risk to man other animals and plants. Spent lubricating oil according to Atuanya, (1987) affects soil physical, biological and chemical properties. However, used oil is a very serious waste management problem and is dangerous to the environment (Agbogidi, 2010). Also the presence of toxic oil constituents and heavy metals may not be ruled out as their influence on crop plant is quite enormous (Agbogidi et al., 2007).

The spent lubricating oil contaminated soil has been used to raise tomato, red beans, pepper e.t.c. in the past to determine their growth response in such soils,(Annoliefo and Vwioka, 2000). but no research work has been done on Adansonia digitata. Therefore this study was carried out to examine the germination and growth-response of Adansonia digitata. seeds and seedlings to different levels of spent lubricating oil contaminated soils.

\section{MATERIALS AND METHOD}

\section{Experimental Site}

The experiment was carried out at the nursery of Forestry Technology Department of Federal College of Forestry, Ibadan, Oyo state Nigeria. The nursery is located at Jericho area of Ibadan Northwest local government area of Oyo state, It is on latitude $7^{0} 26^{\prime} \mathrm{E}$ and longitude $3^{0} 51^{\prime} \mathrm{N}$ of the Greenwich meridian. Its annual rainfall is about $1,300-1,500 \mathrm{~mm}$ while the annual temperature is $26^{\circ} \mathrm{C}$, the average relative humidity is about $65 \%$ (FRIN meteorological station. 2018)

\section{Procurement Of Materials}

The seeds of digitata were collected from a mother tree within the Federal College of Forestry. lbadan. Top soil was collected at Agricultural Technology Department AGT farm practical plot within the College premises. Spent lubrication oil was collected from the mechanic section of the College. The weighing balance was obtained from the Agricultural Technology Department; polythene pots, pen, vernier caliper, notebook, metre rule, paper cellotape were procured at Aleshinloye market. lbadan, OyoState.

\section{Method}

The seeds of Adansonia digitata were extracted by crushing the fruits. The extracted seeds were washed in running water. During this process seeds that were not viable were seen floating in the container were removed and discarded while the viable seeds settled at the base of the container were subjected to pretreatments. The seeds were pretreated by soaking in boiled water and then left for 24 hours before sowing. They were sown in polythene pots of size $24.5 \mathrm{~cm} \mathrm{x} 14 \mathrm{~cm}$ filled with the mixture of $3 \mathrm{~kg}$ of topsoil and spent lubrication oil at varying levels.

The treatment combinations were: 
- Treatment $1 \longrightarrow 3 \mathrm{~kg}$ of top soil (control)

- Treatment $2 \longrightarrow 3 \mathrm{~kg}$ of top soil $+20 \mathrm{ml}$ ofS.L.O

- Treatment $3 \longrightarrow 3 \mathrm{~kg}$ of top soil $+40 \mathrm{ml}$ ofS.L.O

- Treatment $4-+3 \mathrm{~kg}$ of top soil $+60 \mathrm{ml}$ of S.L.O

- Treatment $5 \longrightarrow 3 \mathrm{~kg}$ of top soil $+80 \mathrm{ml}$ of S.L.O

- Treatment $6 \longrightarrow 3 \mathrm{~kg}$ of top soil $+100 \mathrm{ml}$ of S.L.O

- Treatment $7 \longrightarrow 3 \mathrm{~kg}$ of top soil $+120 \mathrm{ml}$ of S.L.O

- Treatment $8 \longrightarrow 3 \mathrm{~kg}$ of top soil $+140 \mathrm{ml}$ of S.L.O

\section{Experimental Design}

The experiment was set up in a Completely Randomized Design (CRD). There were eight treatments .each treatment was replicated four times with four seeds per pot making a total of 128 seeds. The parameters assessed include; Germination Percentage (\%), Stem Diameter ( $\mathrm{mm}$ ), Seedling Height $(\mathrm{cm})$,Number of leaves and Leaf Area $\left(\mathrm{cm}^{2}\right)$. Data collected were subjected to Analysis of Variance (ANOVA)and means were separated using Duncan Multiple Range Test (DMRT).

\section{RESULTS AND DISCUSSION}

Table 1: Germination Percentage Of Adansonia Digitata Seedlings

\begin{tabular}{|c|c|c|c|c|}
\hline \multirow{2}{*}{$\frac{\bar{T}}{T}$} & of $\mathrm{s}$ & No of seed & 5 of & ation \% \\
\hline & 16 & 5 & 11 & 31.25 \\
\hline $\mathrm{T}_{2}$ & 16 & 4 & 18 & 25.00 \\
\hline $\mathrm{T}_{3}$ & 16 & 2 & 20 & 12.25 \\
\hline $\mathrm{T}_{4}$ & 16 & 3 & 31 & 18.75 \\
\hline $\mathrm{T}_{5}$ & 16 & 3 & 31 & 18.75 \\
\hline $\mathrm{T}_{6}$ & 16 & 4 & 33 & 25.00 \\
\hline $\mathrm{T}_{7}$ & 16 & 2 & 32 & 12.50 \\
\hline $\mathrm{T}_{8}$ & 16 & 3 & 39 & 18.75 \\
\hline
\end{tabular}

Table1 above showed that germination was affected by the presence of spent lubricating oil. Significant reduction was observed in the germination percentage of A. digitata seeds sown in oil contaminated soils when compared with seeds sown in uncontaminated soil. Days of germination were also delayed as it took seeds in the contaminated soil longer time to germinate according to the level of concentration of spent lubricating oil that was applied. Similarly, all the seeds planted in various levels of contaminated soil germinated but the number significantly reduced ( $\mathrm{p} \geq 0.05$ ) with increasing oil level in the soil. $\mathrm{T}_{8}$ managed and struggled to germinate but the plant showed evidence of shrinkness, unhealthy, yellowing of leaves, necrosis (die-back) and growth retardation. This supported the findings of De Jong,(1980) who noted that the embryo of seed tend to be injured or killed if it comes in contact with spent oil.

As a result the seedlings gave different response to different levels of concentration of the spent lubricating oil added to the soil. 


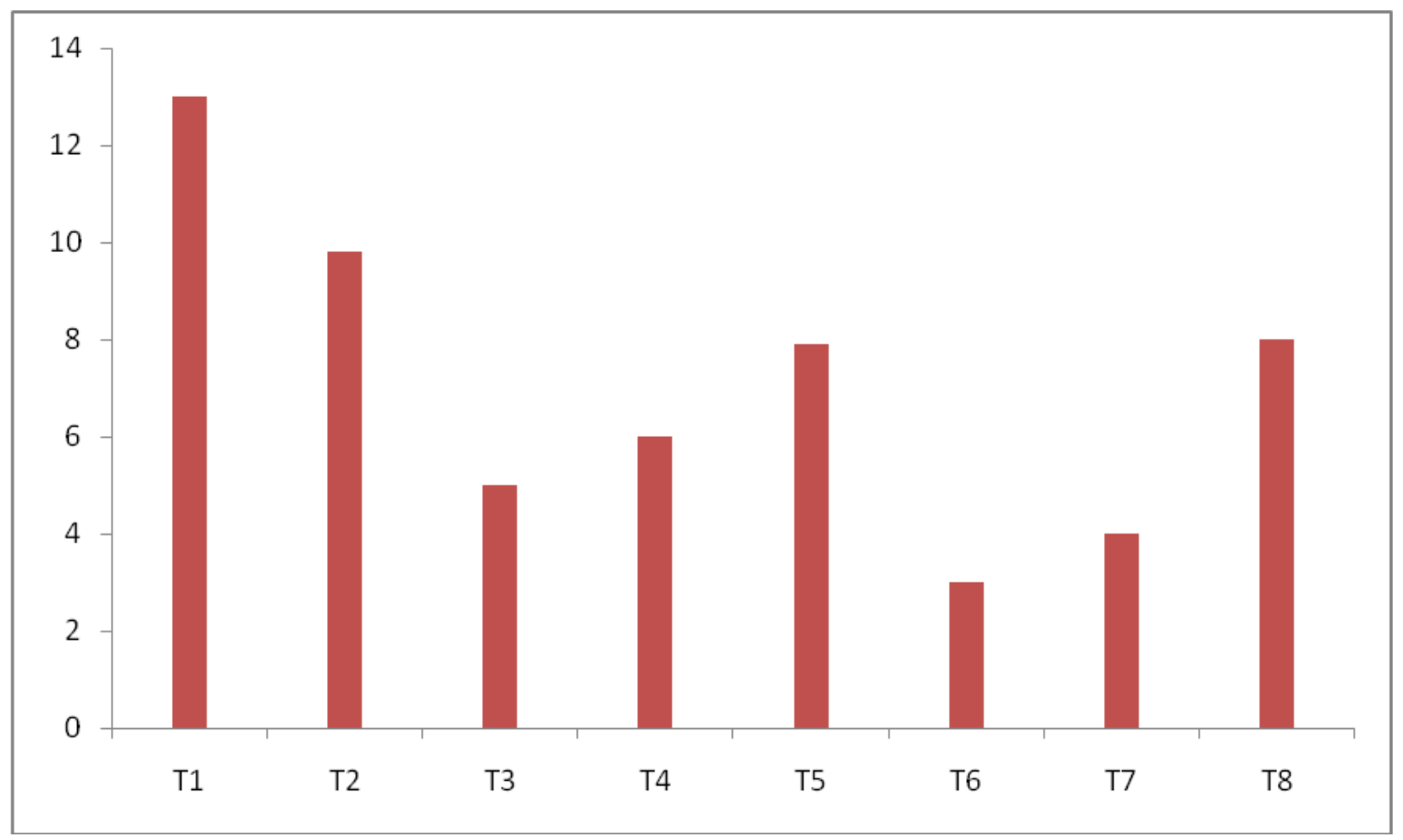

Figure I: Mean Height (Cm) For Adansonia Digitata Seedlings .

Figure 1 above showed that $T_{1}$ (control) had the highest performance in height with a mean value of

$12.77 \mathrm{~cm}$. followed by $\mathrm{T}_{2}(20 \mathrm{ml}$ of SLO + top soil) with a mean value of $9.63 \mathrm{~cm}$, while the least performance was observed in T6 ( $100 \mathrm{ml}$ of SLO+ top soil) with a mean value of $3.1 \mathrm{lcm}$. Furthermore, the various reduction in growth characteristics measured were spent lubricating oil concentration dependent, this was brought about by the effect of the SLO in the soil which inhibited the growth of the plants; although $\mathrm{T}_{2}(20 \mathrm{ml}$ of SLO + top soil) performed best when compared to other seedlings in contaminated soils. This result supported the findings of Agbogidi (2010) who reported that since uptake of water and salt (iron) is carried out by root undisturbed, seedlings could have absorbed enough nutrients compared to the seedlings exposed to soil treatment with diverse levels of spent lubricating oil. However, table 2showed that there was no significant difference among the treatments at 5\% level of probability.

Table 2 : Analysis Of Variance For Seedling Height

\begin{tabular}{|llllll|}
\hline SV & DF & SS & MS & F & P-VALUE \\
TRT & 7 & 318.62 & 45.51 & $1.15 \mathrm{NS}$ & 0.37 \\
ERROR & 24 & 949.14 & 39.54 & & \\
TOTAL & 31 & 1267.77 & & & \\
\hline
\end{tabular}

Note: Ns- not significance $(\mathrm{p}>=0.5)$ 


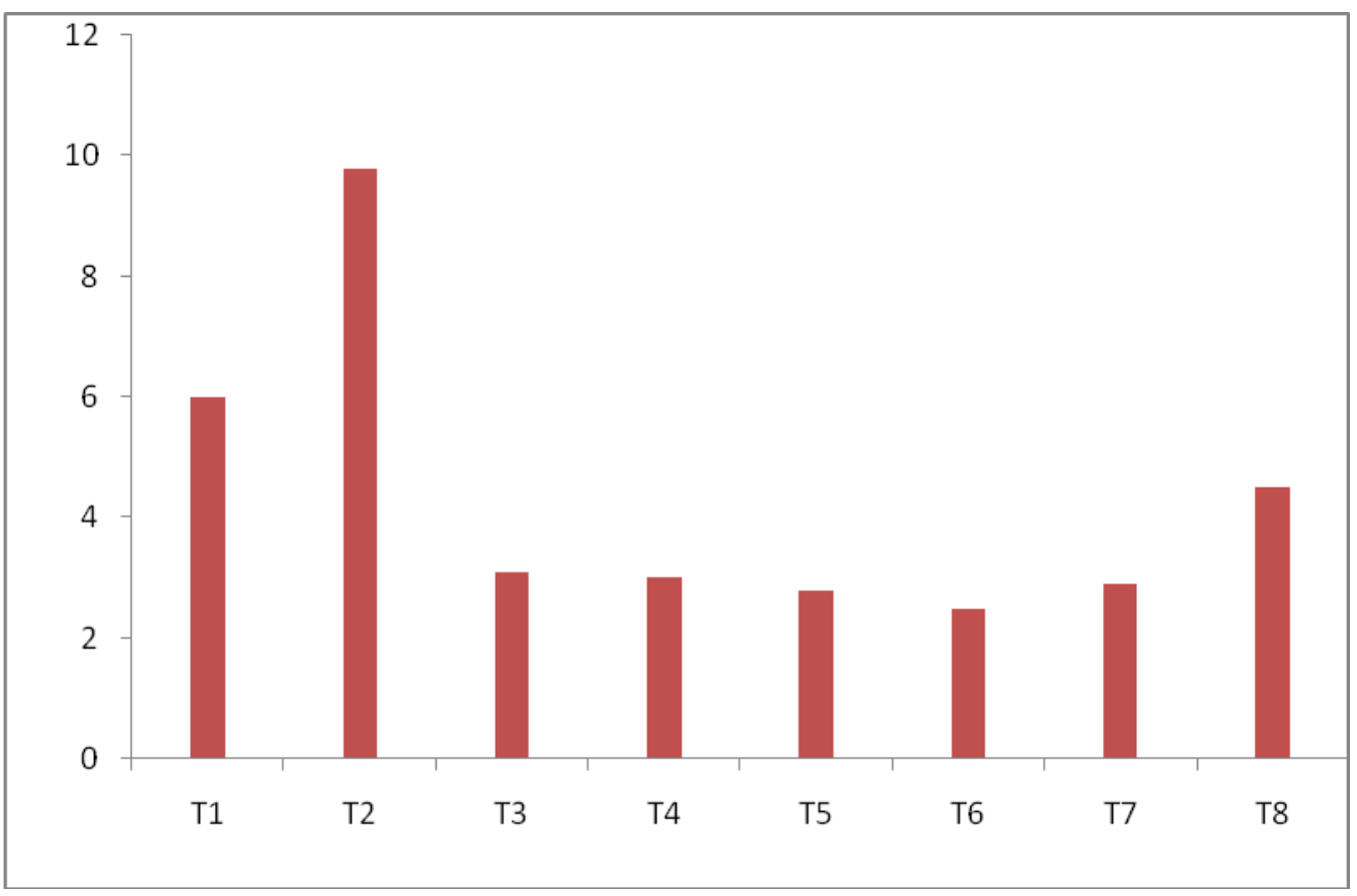

Figure 2 : Mean Leaf Production For Adansonia Digitata Seedlings .

Figure 2 revealed that seedlings in $\mathrm{T}_{1}$ (control) gave the highest mean leaf production of 5.40. followed by $\mathrm{T}_{2}(20 \mathrm{ml}$ of SLO + top soil $)$ with a mean value of 5.15 , while $\mathrm{T}_{6}$ had the least performance with mean value of 2.43. Furthermore, the result showed that SLO can affect the leaf production in plants but at lower concentrations the seedlings can still adapt. Consequently, seedlings in higher concentrations showed evidence of shrinkness, yellowing of leaves as well as stunted growth. This result therefore supported the findings of Atuanya (1987) who pointed out that as hydro carbon from oil contaminated soils accumulate, translocation is affected due to obstruction of the xylem and phloem vessels, hence reduction in photosynthesis tend to reduce the matter content components of the plants. Table 3 showed that there was no significant difference among the treatments applied at $5 \%$ level of probability.

Table 3 : Analysis Of Variance For Seedling Height

\begin{tabular}{|llllll|}
\hline SV & DF & SS & MS & F & P-VALUE \\
TRT & 7 & 32.62 & 4.63 & $0.63 \mathrm{~ns}$ & $>0.05$ \\
ERROR & 24 & 226.14 & 9.42 & & \\
TOTAL & 31 & 258. & & & \\
\hline
\end{tabular}

Note : ns - not significant $(\mathrm{p}>=0.05)$ 


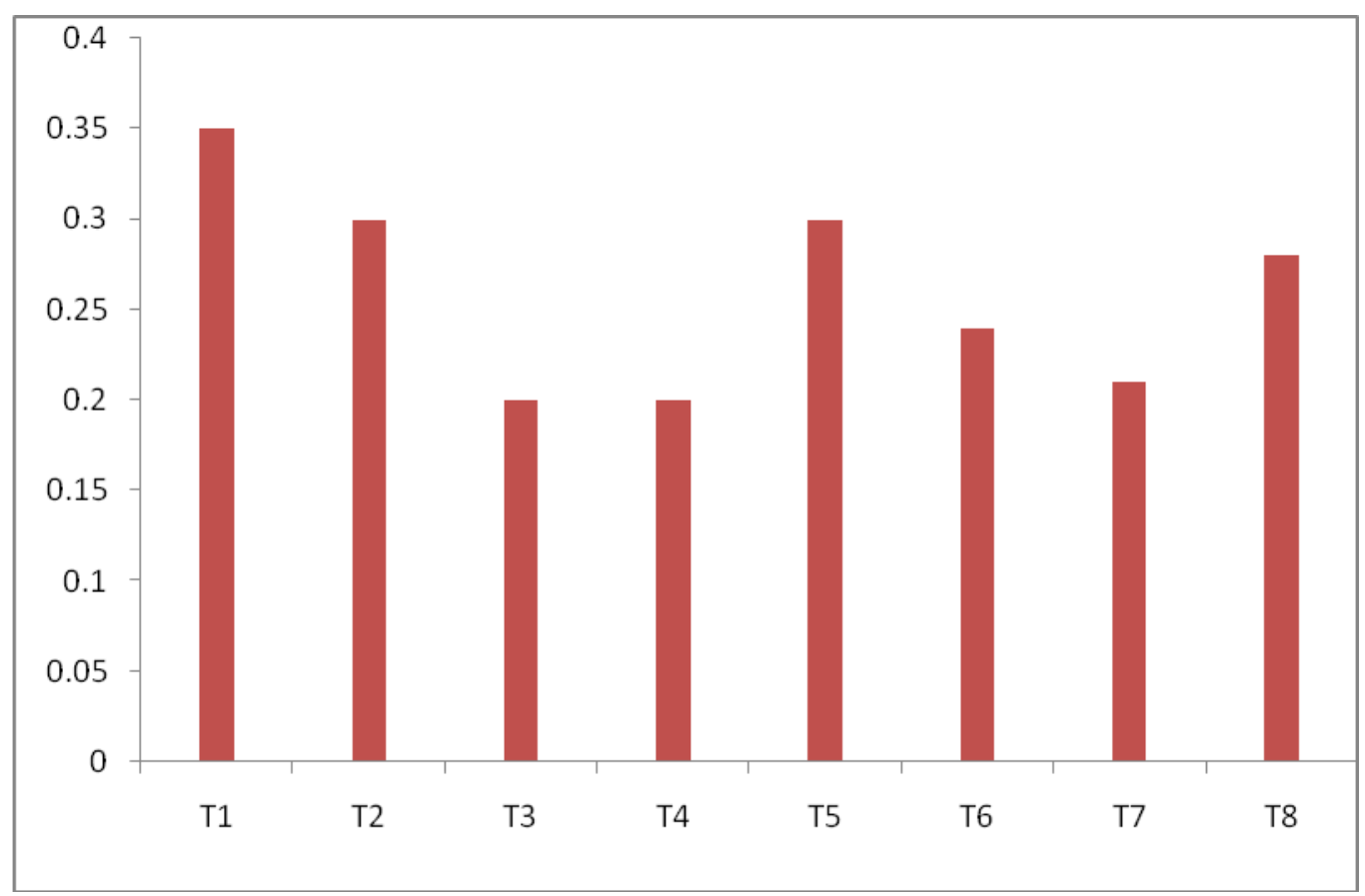

Figure 3 : Mean Stem Diameter (Mm) For Adansoni Adigitata Seedlings .

Figure 3 above indicated that $\mathrm{T}_{1}$ (control) had the highest performance in stem diameter with mean valueof $0.35 \mathrm{~mm}$, followed by $\mathrm{T}_{5}$ with a mean value of $0.32 \mathrm{~mm}$, while $\mathrm{T}_{3}$ and $\mathrm{T}_{4}$ showed the least performancewith the mean value of $0.21 \mathrm{~mm}$ respectively. Here, the treatments gave different response to differentlevels of concentration of SLO applied to the soil. This report was in consonance with the findings of Agbogidi and Ejemete (2005) who noted that the level of oil in soil seemed to exert significant influenceon plant species and agricultural lands due to the presence of heavy metals which is responsible for the reduction in plant growth characters mobilization as well as the metabolic activities ofthe plants. Table 4indicated that there was significance difference among the treatment used at $5 \%$ level of probability.

Table 4 : Analysis Of Variance For Seedling Height

\begin{tabular}{llllll|}
\hline SV & DF & SS & MS & F & P-VALUE \\
TRT & 7 & 0.06 & 0.01 & $0.18^{*}$ & 0.03 \\
ERROR & 24 & 1.18 & 0.05 & & \\
TOTAL & 31 & 1.24 & & & \\
\hline
\end{tabular}

Note : Significant at $5 \%$ level of profitability $(\mathrm{p}>=0.05)$ 


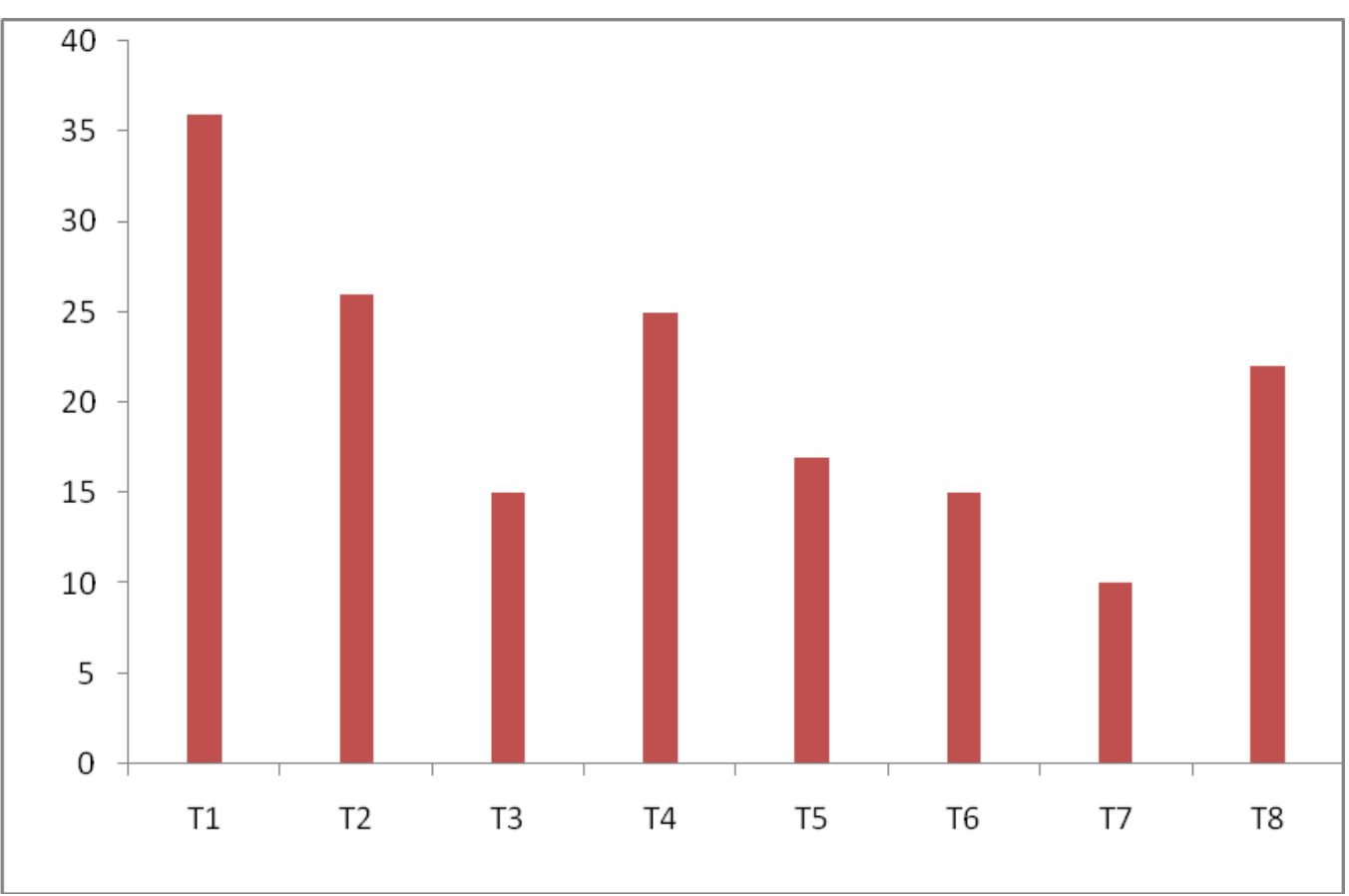

Figure 4 : Mean Leaf Area (Cmz) For Adansoniadigitala Seedlings .

Figure 4 above showed that $\mathrm{T} 1$ (control) had the highest performance in leaf area $(38.60 \mathrm{~cm} 2)$, followed by $\mathrm{T}_{3}\left(20 \mathrm{ml}\right.$ of $\mathrm{SLO}+$ top soil) $(26.68 \mathrm{~cm} 2)$, while $\mathrm{T}_{7}$ produced the least performance with mean value of $10.65 \mathrm{~cm} 2$. Furthermore, the growth reduction in leaf area could be interpreted as being due to the effect of SLO which could have shown up thereby distorting and reducing the number of stomata per unit area of the leaf thus affecting photosynthetic process and consequently, the amount of photosynthates produced. This result was in support of the findings of Agbogidier et al., (2007) who noted that the presence oftoxicoil constituents and heavy metals may not be ruled out as their influences on crop plant are quiteenormous.

Table 5 indicated that there was no significant difference among the treatments applied at $5 \%$ level of probability.

\begin{tabular}{|llllll|}
\hline SV & DF & SS & MS & F & P-VALUE \\
TRT & 7 & 2320.94 & 331.56 & $1.17 \mathrm{~ns}$ & 0.36 \\
ERROR & 24 & 6804.06 & 283.50 & & \\
TOTAL & 31 & 9125.00 & & & \\
\hline
\end{tabular}

Note: $n s$ - not significant $(\mathrm{p}>=0.5)$

\section{CONCLUSION}

It is commonly known that spent lubricating oil is a soil contaminant, but no one has been able to quantify it and assign a number to the value of damage. SLO contaminates the soil and hereby does notgive way for soil aeration. All treatments applied at different rates consequently affected 
the growth of Adansonia digitata at different levels. Also the study revealed that although seedlings of Adansonia digitata can thrive in spent lubricating oil, there is a level that it can tolerate. this can be seen in seedlings planted in $40 \mathrm{mls}, 60 \mathrm{mls}, 80 \mathrm{mls}, 120 \mathrm{mls}$ and $140 \mathrm{mls}$ of SLO contaminated soil as seedlings showed evidence of shrinkness, unhealthiness, yellowing of leaves, necrosis and growth retardation. It is therefore recommended that Adansonia digitata should be adopted for reclamation of land where the use of SLO is prominent to an extent.

\section{REFERENCES}

Agbogidi O.M (2010). Response of African oil bean (Pentaclethra macrophylla) (Benth) seeds to soil

contaminated with spent lubricating oil. African Journal of Environmental Science and Technology, Volume4 (5): $492-494$.

Agbogidi OM, Ejemete O.R (2005). An assessment ofthe effects of crude oil pollution on soil properties, germination and growth of Gambaya albida (L). Uniswa. Res. J. Agric., Sci. Technol., 8(2): 148-155.

Agbogidi O.M, Eruotor P.G, Akpairobi S.O, NnajiG.U (2007). Heavy metals content of maize Zeaniays) grown in soil contaminated with crude oil. International Journal of Botany, Volume 3(4): 384-3 89.

Annoliefo G.O, Vwioko D. E. (2000). Effect of spent engine oil as a soil contaminant on the growth of red beans and pepper. Journal of Agriculture Forestry and Fisheries, 1 .pp $21-25$.

Atuanya E.I (1987). Effect of waste engine oil pollution on physical and chemical properties of soil. A case study of waste oil contaminated delta soil in Bendel state. Nigerian Journal of Applied Science. Volume 5: 155-176. '

Claire Soares, (2008). The tree life ( and its super fruit), the independent Thursday, $17^{\text {th }}$,July,2008. De Jong,E (1980).

The effect of crude oil spill in cereals. Journal of environmental pollutvolume22: 187 - 196. FAO (1988).Journal ofterrains interim assessment.north America. Volume 8(2) pp 216 - 222. Wang J, JiaC.R,Wong CK, Wong P.K.(2000). Characteristics of polycyclicaromatic hydrocarbon created in lubricating aromatic hydrocarbon 5 created in lubricating oil. Water.air and soil pollution, 120: 381-396. 